book argues that of three possible attitudes to death, described as denial, acceptance and rebellion, rebellion is the most appropriate. This is not borne out by experience gained from hospice work where many of the most peaceful deaths are in patients who accept their imminent death and some of the most distressing are in patients who cannot accept the inevitable. Nevertheless, the book gives a thought-provoking, wellargued justification of a different attitude to death and acts as a reminder that all patients are different in their codes of belief and lifestyle, and that no generalisation about appropriate attitudes to death will be true of all people.

The book is written from a secular point of view and the approach to religious attitudes is somewhat insensitive given that much valuable work on dying and death has been pioneered by those of a strong religious conviction. The suggestion that faith in life after death is really a sophisticated form of death-denial is particularly unacceptable.

Much of the material in the book discussed so far arises in the first chapter and the book becomes less difficult to read in subsequent chapters. The author does not expect us to agree with him. In the preface he states that he hopes the book will be found 'at least interesting and frequently provocative by those who dissent'.

The conclusion to the first part of the book is that the ideal is 'death with dignity'. This is presented in a sensitive and interesting manner and few people would argue with it.

There are controversial aspects to the second half of the book, not surprisingly, given the different attitudes held towards suicide. Ten suicide case studies are described and these raise the whole issue of how to define suicide and show clearly that this is more difficult than might initially be supposed. The author uses the concept of death with dignity to evaluate suicide and concludes that it is occasionally an acceptable act. At the same time he warns against the romanticisation of death and ideologies which suggest suicide is praiseworthy.

The examples of a severely injured American who expressed a wish to discontinue life-saving treatment but was not allowed to do so, and of the rights of mentally retarded people or people on life-support systems to be given or not given treatment are discussed in the last chapters of the book. The overriding conclusion drawn by the author is the right of a patient to be treated with dignity and compassion by his fellow man. When this is the main concern of those involved the decisions to be made are that much easier.

As Professor Momeyer says of one patient, the main tragedy is 'that there is no one in all the world who could have wiped his brow and offered him some small measure of human warmth'.

The book is simply written even though it includes some complicated arguments. If it succeeds in reminding us to treat our fellows with respect and dignity it will have achieved much it sets out to do.

JACQUELINE A FISHER Ellenor Foundation Hospice Care Team Dartford

\section{Health, Rights and Resources}

Edited by Peter Byrne, 201 pages, London, $£ 16.95$ hbk, King Edward's Hospital Fund for London, 1988

King's has done it again. For the third year Peter Byrne has collected a series of essays which are topical, in that they address problems that judges and legislators should now be considering, while in no sense being ephemeral. They merit the hard covers in which the King's Fund and the OUP have presented them.

The most philosophical of the collection is John Harris's analysis of the QALY, concluding: 'If QALYs are implemented they would constitute a denial of the most basic civil rights'. The others are more immediately practical: for example John McEwan, in the longest piece in the book, provides a social study of the present state of family planning which will interest patients and administrators as much as doctors. The odd-ball is Arnold Simanowitz, the dreaded Director of Action for the Victims of Medical Accidents, who almost persuades one that defensive medicine is ethically respectable.

What makes this collection particularly suitable as a source book for students of medical ethics, such as those taking the Apothecaries' Diploma, is the balance. The editor opens with a key essay on the ethical, social and legal issues raised by AIDS at the present stage of the epidemic; for background Roy and Dorothy Porter give a factual social history of the enforcement of public health in this country.
Similarly Professor Capron from the University of Southern California describes the work of the President's Commission for the Study of Ethical Problems in Medicine, giving a factual background to Simon Lee's discussion of the respective roles of judges and Parliament as sources of medical law.

So much of English law concerns itself with 'wrongs'. The thrust of the European Court, like the title of these essays, is more on 'rights' even though Simon Lee says 'I wish that the growing body of international human rights law was called human duties law. But it isn't'.

One would have thought that everything that could have been written about abortion had by now been written, but by starting from the angle of rights and duties John Eekalaar gives new insights in his piece on a mother's duty to her unborn child.

In promoting health government is not entirely reliant on legislation; in the case of AIDS, mass education has been used. But, where medical legislation is called for, Lee complains that 'legislators consistently duck sensitive moral dilemmas and leave the judges to resolve the ensuing mess'.

Charles Kingsley may well have drawn our attention to the mistake of fancying that legislative reform is socia reform or that men's hearts can be changed by Act of Parliament'. More appropriately, by the application of medical ethical thinking we should today be aiming to change the hearts of the men who pass Acts of Parliament. This book provides raw material for such groups. Judges and politicians could profitably read these essays too.

JAMES FISHER Past Master, Society of Apothecaries

\section{Rights and Responsibilities of Doctors}

British Medical Association
Professional Division, 135 pages,
London, £7.95, pbk, BMA, 1988

This book's stated aim is to provide a practical guide to certain aspects of the law as it affects doctors and as such it should be welcomed. It avoids ethical questions entirely, advising reference to the association's Handbook of Medical Ethics. 
It is written as much for the layman as for the medical profession and should prove equally valuable to health service adminstrators and local authority officers.

There are well written sections dealing with consent to treatment, confidentiality and advertising as well as more specialised areas such as the role of doctors in the armed forces, on board ship and in the prison service.

This is obviously not a book to be read at a single sitting. However, for a book that will be referred to for information on a specific topic, and often when time is limited, the layout serves to obstruct rather than help the reader.
The index is placed at the front of the book, hidden between a comprehensive glossary of legal terms and a bewildering table of cases, circulars and notices.

If the book has a major failing it is that it was neither conceived nor written as a book but rather as an internal document for BMA use. There is a world of difference between an aidememoire for an experienced advisor and a reference text for the non-expert.

Surprisingly, perhaps, for a book advising doctors on their responsibilities there is precious little in it regarding misconduct. The reader is directed towards the GMC guide to professional conduct and discipline.
To their credit the authors have solicited suggestions for future revisions and additions in their introduction. A reworked layout, a broadening of its horizons to include at least a little advice on situations which may lead to disciplinary proceedings and a better disguise of its origins should make the second edition less of a disappointment.

Until then, this edition, already out of date, and better regarded as essential rather than enticing, should be in every practice library.

DR MARTYN LOBLEY Gallions Reach Health Centre, Thamesmead, London, SE28 8BE 